\title{
Regulatory aspects and evidences of melatonin use for sleep disorders and insomnia: an integrative review
}

\author{
Aspectos regulatórios e evidências do uso de melatonina em distúrbio do sono e insônia: \\ uma revisão integrativa
}

Ana Paula Rosinski BUENO', Flávia Medeiros SAVI², Izabel Almeida ALVES³, Vanessa Adelina Casali BANDEIRA ${ }^{1}$

\begin{abstract}
Background: Insomnia is a sleep disorder characterized by difficulty of falling asleep or maintaining sleep, which affects different age groups. Currently, melatonin is used as a therapeutic treatment in cases of insomnia in children, adults, and elderly people. Objective: To evaluate the effectiveness of melatonin in sleep disorders, its dosage, potential adverse effects, as well as labeling laws and regulations in Brazil. Methods: This integrative review was carried out using the Cochrane Library, Medline (Pubmed), and Science Direct databases. Twenty-five articles and three documents available on the Brazilian Society of Endocrinology and Metabology (SBEM) and National Health Surveillance Agency (ANVISA) websites published between 2015 and 2020 were selected to be evaluated in full. Results: It was found that in most of the selected articles the use of melatonin reduces sleep latency. The effective melatonin doses varied according to each age group, from 0.5 to $3 \mathrm{mg}$ in children, 3 to $5 \mathrm{mg}$ in adolescents, 1 to $5 \mathrm{mg}$ in adults, and 1 to $6 \mathrm{mg}$ in elderly people. Side effects are mild when taking usual doses. In Brazil, no registered drug and current regulation on the use and marketing of melatonin has been identified. Conclusion: The use of melatonin is an alternative therapy that can be used for sleeping disorders. According to the evidences found, it did not demonstrate toxicity or severe side effects, nor dependence even when administered at high doses, suggesting that it is a safe medication to treat patients of different ages suffering from sleeping disorders.
\end{abstract}

Keywords: Melatonin; Sleep Wake Disorders; Pineal Gland.

RESUMO

Antecedentes: Insônia é um distúrbio do sono caracterizado por dificuldade de iniciar e manter o sono, afetando diferentes faixas etárias. Atualmente, a melatonina é utilizada no tratamento de insônia em crianças, adultos e idosos. Objetivo: Avaliar a eficácia da melatonina nos distúrbios do sono, posologia e potenciais efeitos adversos, bem como a regulamentação vigente no Brasil. Métodos: Trata-se de uma revisão integrativa, os artigos foram identificados nas bases de dados Cochrane Library, Medline (Pubmed) e Science Direct, totalizando 25 artigos, e foram selecionados três materiais disponíveis no site da Sociedade Brasileira de Endocrinologia e Metabologia e Agência Nacional de Vigilância Sanitária, publicados entre 2015 e 2020. Resultados: Verificou-se na maioria dos artigos selecionados que a melatonina reduz a latência do sono. Quanto as dosagens de melatonina identificou-se variação em cada faixa etária, para crianças de 0,5 a 3mg; adolescentes de 3 a $5 \mathrm{mg}$; adultos de 1 a $5 \mathrm{mg}$ e idosos $1 \mathrm{mg}$ a $6 \mathrm{mg}$ demostraram serem eficazes. Em doses habituais os efeitos colaterais são leves. No Brasil, não foi identificado medicamento registrado e regulamentação vigente sobre o uso e comercialização de melatonina. Conclusão: A utilização da melatonina é uma alternativa que pode ser utilizada em distúrbios do sono. De acordo com as evidências encontradas, não demonstrou toxicidade ou efeitos colaterais severos, nem dependência mesmo em doses elevadas, sendo, portanto, segura para tratamento de pacientes desde crianças a idosos que sofrem de distúrbios do sono.

Palavras-chave: Melatonina; Transtornos do Sono-Vigília; Glândula pineal.

${ }^{1}$ Universidade Regional do Noroeste do Estado do Rio Grande do Sul, Departamento de Ciências da Vida, Ijuí RS, Brazil.

${ }^{2}$ Queensland University of Technology, Centre in Regenerative Medicine, Institute of Health and Biomedical Innovation, Kelvin Grove, Australia.

${ }^{3}$ Universidade Federal da Bahia, Faculdade de Farmácia, Departamento do Medicamento, Salvador BA, Brazil.

APRB (D) https://orcid.org/0000-0002-3227-1492; FMS (ID) https://orcid.org/0000-0003-0067-8308; IAA (D) https://orcid.org/0000-0002-8935-6542;

VACB (iD) https://orcid.org/0000-0002-6888-1532

Correspondence:Vanessa Adelina Casali Bandeira; Email: vanessa.acbandeira@yahoo.com.br.

Conflict of interest: There is no conflict of interest to declare.

Authors' contribution: APRB, IAA, VACB: contributed to the conception and design of the research project, data collection, data analysis and interpretation and writing of the article; FMS: contributed to the interpretation and editing of the article.

Received on August 05, 2020; Received in its final form on December 20, 2020; Accepted on December 22, 2020. 


\section{INTRODUCTION}

Insomnia is a sleep disorder characterized by difficulty in falling asleep or maintaining sleep. It is defined as the persistent difficulty in falling and staying asleep, problems with sleep duration and maintenance and sleep quality ${ }^{1}$. Insomnia occurs in different age groups and can last for weeks, months, or longer periods. In these cases, it is considered as a chronic disease when it remains for three months or more and affects the individual's occupational performance and daily routine $^{2}$. The prevalence of insomnia varies between 10 to $20 \%$ in the general population, and approximately $50 \%$ of these people live with this condition in a chronic way3. In China, the prevalence of insomnia is $15 \%^{4}$, followed by Spain $21.1 \%^{5}$ and Brazil, reaching above $30 \%$ of the population ${ }^{6,7}$ the gold standard for sleep assessment, this study aimed to describe the objective prevalence of insomnia in the São Paulo, Brazil, Epidemiologic Sleep Study cohort of 1,101 adults (20-80 years old.

Non-pharmacological treatments can help the patient in improving symptoms, including sleep hygiene, stimulus control, relaxation techniques, among other methods $^{8,9}$. Pharmacological treatments used to treat insomnia include selective agonists of the $\gamma$-aminobutyric acid type A (GABA-A) receptor, sedative antidepressants, melatonin and melatoninergic agonist, sedative antipsychotics, benzodiazepines, anticonvulsants, antihistamines, and herbal medicines such as Valeriana officinalis ${ }^{3,89}$. Widely used, the minor tranquilizers benzodiazepines can cause tolerance, dependence, and withdrawal syndrome, as well as being considered inappropriate for elderly people due to its high risk of accidents, including falls and concomitant fractures ${ }^{3}$.

Commonly known as melatonin, n-acetyl-5-methoxytryptamine is a neurohormone, a small lipophilic molecule produced by the pineal gland. Among its functions, the chronobiotic effect is associated with the regulation of the endogenous clock in relation to the photoperiod ${ }^{10}$. A physiological function of endogenous melatonin is to reinforce the behavior related to darkness. Its production increases about two hours before bed. In addition, during the night, melatonin is responsible for transmitting information to the brain and other organs of the central nervous system about the duration of sleep, reducing the watch signal, as well as promoting fatigue and inducing sleep ${ }^{11,12}$. Li et al. ${ }^{13} \mathrm{Embase}$, Cochrane Library, ClinicalTrials.gov, and Web of Science reviewing exogenous melatonin as a treatment for secondary sleep disorders suggested that exogenous melatonin improves sleep quality, reduces onset latency, and increases total sleep time.

Classified as a non-prescription supplement in the United States of America, melatonin is widely used as a natural product, among all age groups, including children ${ }^{14}$. Research conducted with 31 supplements in Guelph, Ontario, Canada has showed low quality of melatonin formulations, with high concentration variability between samples and batches and the presence of serotonin in 8 of the evaluated supplements ${ }^{15}$. In Brazil, the number of medical prescriptions for the use of melatonin to treat insomnia has increased, however their commercialization is available only in compounding pharmacies. Currently, only one supplier of pharmaceutical products is authorized to distribute melatonin in Brazil, and solely to compounding pharmacies ${ }^{16}$. Although the use of melatonin for the treatment of insomnia have expanded in recent years, information about its potential adverse effects and drug interactions are still limited. The National Health Surveillance Agency (ANVISA) newsletter $(2019)^{16}$ reports that marketed medications must have proof of safety, efficacy, and quality in Brazil, but due to an injunction that allows the sale of raw materials, melatonin is available overthe-counter ${ }^{17}$. Moreover, the Brazilian Sleep Society considers that the use of melatonin to treat circadian rhythm disorders is already established, but the results for insomnia are not consistent, despite some positive results in specific populations and a good tolerability and safety profile, with few side effects $^{18}$.

These results demonstrate the need for greater control over the production and marketing of melatonin supplements. It is necessary to build and develop a more effective health care and identify the best practices for health professional bodies, especially prescribers and pharmacists who work directly in the prescription and provision of this medication to patients. In this perspective, this study aimed to evaluate the effectiveness of melatonin for sleep disorders and melatonin associated symptoms, dosage, potential adverse effects, as well as the law regulations of the drug in Brazil.

\section{METHODS}

This article is an integrative review in which the six methodological steps described by Mendes, Silveira and Galvão ${ }^{19}$ were followed: (i) identification of the theme and selection of the research question to carry out the integrative review; (ii) establishment of criteria for inclusion and exclusion of studies; (iii) definition of the information to be extracted from the selected studies; (iv) evaluation of studies included in the integrative review; (v) interpretation of results; and (vi) presentation of the review.

Data collection was performed using Cochrane Library, Medline (Pubmed), and Science Direct databases. To perform the searches, Health Sciences Descriptors (Decs) were used in Portuguese and English, and the articles were selected according to the objective of the project and including the following key words: melatonin, pineal gland, sleep disorders, and insomnia. In addition, for the regulatory aspects, the Brazilian Society of Endocrinology and Metabology (SBEM) and the ANVISA websites were accessed using the descriptor "melatonin". Fifty-six documents were found using the 
SBEM and two documents were selected to be evaluate in full. Thirty-four documents were identified using the ANVISA website and one document was selected to be assessed in full.

The article search using the databases was based on the following criteria: articles published between 2015 and 2020, in Portuguese or English. Articles that were not in the defined languages, did not have any descriptors of interest, or that were outside the defined publication period were excluded. Reviews, meta-analysis, cohort studies, and randomized clinical trials were selected.

For the selection of articles, an initial search based on title and abstract was carried out in the database. Then, a new selection was made with the reading of the articles in full, according to the Figure 1.

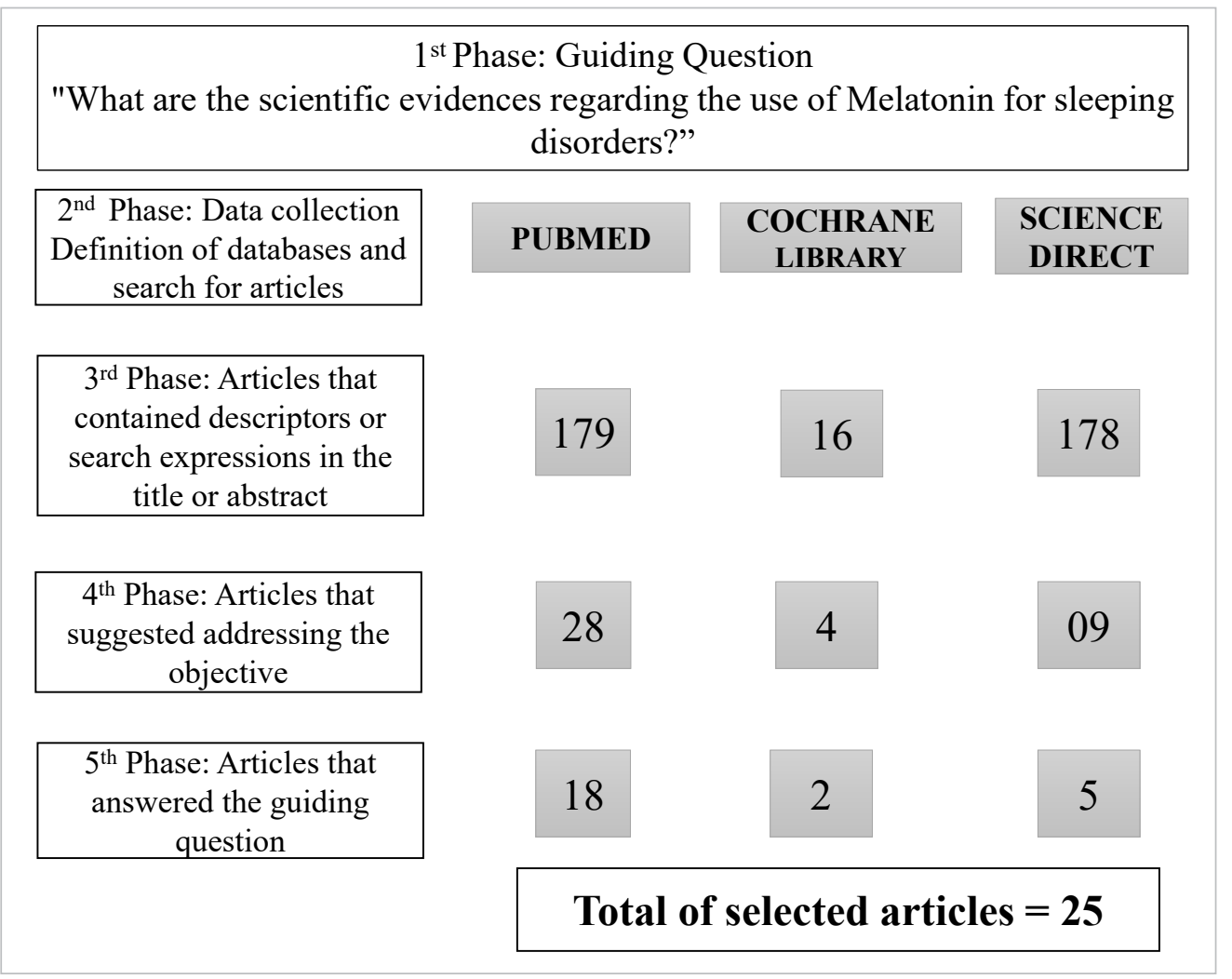

Figure 1. Summary of the article selection process.

\section{RESULTS}

The final selection consisted of 25 articles and three documents identified in the Brazilian websites. Table 1 summarizes the characteristics of the articles according to authors, year of publication, and database of publication.

No articles were identified reporting the current regulations of melatonin in Brazil. The only information found was that the commercialization of melatonin is authorized only for compounding pharmacies, and must be purchased from the Active Pharmaceutica supplier ${ }^{16,17}$. Similarly, no drug is registered with melatonin as the active ingredient. However, in Europe, a medicine registered under the trade name of Circadin" is available in the market.

Table 2 shows the characteristics of the selected articles according to the study design, population, dosage, intervention evaluation, therapeutic and adverse effects of melatonin. Of the 25 studies found, 22 showed positive results regarding the use of melatonin in insomnia disorders and three studies showed ineffective or inconclusive results.

\section{DISCUSSION}

The term circadian is derived from the Latin term circa diem, which means around one day. Circadian rhythms are endogenous oscillations that occur over a 24-hour period. In humans, this cycle lasts an average of 24.2 hours with individual variation of 23.7 to 25.3 hours. The waking and sleeping process is strongly influenced by the circadian system ${ }^{24}$.

Currently approved by the Food and Drug Administration (FDA) for the treatment of sleep disorders in elderly people $^{35}$, melatonin has been used for delayed insomnia, sleepwake cycle with periods shorter than 24 hours, sleep correction in the elderly, as an adjuvant in the treatment of autism spectrum disorder, attention deficit hyperactivity syndrome, migraine, anesthesia, metabolic diseases, and polycystic ovary syndrome ${ }^{28}$. The synthetically produced melatonin can be administered exogenously and there are immediate and sustained release formulations available on the market.

Malow and collaborators ${ }^{42}$ report that melatonin is effective for sleep disorders in children and adolescents 
Table 1. Distribution of references included in the study, according to the authors, year of publication, database and journal.

\begin{tabular}{|c|c|c|c|}
\hline Authors & Year & Data base & Periodic \\
\hline Hajak \& Zisapel 20 & 2015 & PUBMED & International clinical psychopharmacology \\
\hline Culpepper \& Wingertzahn ${ }^{21}$ & 2015 & PUBMED & Prim Care Companion CNS Disord \\
\hline Wright et al. ${ }^{22}$ & 2015 & SCIENCE DIRECT & Drugs \& Aging \\
\hline Foley \& Steel ${ }^{23}$ & 2015 & SCIENCE DIRECT & Complementary Therapies in Medicine \\
\hline Williams et al. ${ }^{24}$ & 2016 & PUBMED & Pharmacotherapy \\
\hline Mccleery \& Sharpley ${ }^{25}$ & 2016 & COCHRANE LIBRARY & Cochrane Database of Systematic Reviews \\
\hline Cardinali et al. ${ }^{26}$ & 2016 & SCIENCE DIRECT & Pharmacological Research \\
\hline Chang et al. ${ }^{27}$ & 2016 & PUBMED & JAMA pediatrics. \\
\hline Hohl et al..$^{28}$ & 2016 & SITE SBEM & SITE SBEM \\
\hline $\begin{array}{l}\text { Sociedade Brasileira de } \\
\text { Endocrinologia e Metabologia }{ }^{29}\end{array}$ & 2016 & SITE SBEM & SITE SBEM \\
\hline Auld et al.11 & 2017 & PUBMED & Sleep Medicine Reviews \\
\hline Madsen et al. ${ }^{30}$ & 2017 & PUBMED & Trials journal \\
\hline Riemann et al. ${ }^{9}$ & 2017 & PUBMED & European Sleep Research Society \\
\hline Abdelgadir et al. ${ }^{31}$ & 2018 & PUBMED & Archives of Disease Childhood \\
\hline Maras et al..$^{32}$ & 2018 & PUBMED & Journal Of Child And Adolescent Psychopharmacology \\
\hline Quera-Salva \& Claustrat ${ }^{33}$ & 2018 & PUBMED & Encephale \\
\hline Zwart et al. ${ }^{34}$ & 2018 & PUBMED & Healthcare \\
\hline Myers et al. ${ }^{35}$ & 2018 & PUBMED & Journal of clinical sleep medicine \\
\hline Sletten et al. ${ }^{36}$ & 2018 & PUBMED & Public Library of Science \\
\hline Lewis et al. ${ }^{37}$ & 2018 & COCHRANE LIBRARY & Cochrane Database of Systematic Reviews \\
\hline Anvisa $^{16}$ & 2019 & SITE ANVISA & SITE ANVISA \\
\hline Besag et al. ${ }^{38}$ & 2019 & PUDMED & CNS Drugs \\
\hline Schroder et al. ${ }^{39}$ & 2019 & PUDMED & Journal of autism and developmental disorders \\
\hline Lemoine; Bablon \& Silva ${ }^{40}$ & 2019 & PUBMED & Complementary therapies in medicine \\
\hline Seiden \& Shah ${ }^{41}$ & 2019 & PUBMED & Prim Care Companion CNS Disord \\
\hline Li et al..$^{13}$ & 2019 & PUBMED & Frontiers in neuroendocrinology \\
\hline Malow et al. 42 & 2020 & SCIENCE DIRECT & $\begin{array}{l}\text { Journal of the American Academy of Child \& Adolescent } \\
\text { Psychiatry }\end{array}$ \\
\hline Low, Choo \& Tan ${ }^{43}$ & 2020 & SCIENCE DIRECT & Journal of Psychiatric Research \\
\hline
\end{tabular}

(2-17.5 years) with autism spectrum disorder and insomnia. According to the authors, there was an improvement in sleep quality with no changes in weight, height, body mass index, and pubertal status, and no evidence of developmental delays. Nunes et al. ${ }^{7}$ recommend doses of 0.5 to $3 \mathrm{mg}$ for children and 3 to $5 \mathrm{mg}$ for adolescents. Chang et al. ${ }^{27}$ suggest that melatonin supplementation is a relatively safe and effective way to improve sleep-onset in addition to decreasing the severity of symptoms of atopic dermatitis in children, due to melatonin immunomodulatory, anti-inflammatory, and antioxidant effects, thus improving the skin and helping to maintain the epidermal barrier.

The review demonstrated that the use of melatonin is effective to treat primary and secondary insomnia at different stages of life, from children and teenagers to adults and the elderly. There was also a great diversity in the variables investigated, especially regarding the dose, time of use, and sleep outcomes. Despite of some biases, most studies demonstrated that the use of melatonin for sleep disorders is efficient and safe.

Table 3 shows the dosages of melatonin indicated for each age group according to the publications found.

As for the use in elderly people, Culpepper et al. ${ }^{21}$ report that prolonged-release melatonin formulations are effective in symptoms associated with sleep-onset, however the effects may be limited to individuals over 55 years old who suffer from insomnia. Quera-Salva et al. ${ }^{33}$ evaluated a dose of $2 \mathrm{mg}$ of melatonin administered once a day for three months. The authors found that Circadin ${ }^{\circledR}$ is well tolerated, has no rebound, withdrawal or hangover effects, in addition to not causing drug interactions with antihypertensive, antidiabetic, hypolipidemic or anti-inflammatory drugs, which are the drugs most used by elderly people.

No evidence was found that the use of melatonin (up to $10 \mathrm{mg}$ ) assists in sleep disorders in patients with moderate to severe dementia due to Alzheimer's disease. The doses 


\begin{tabular}{|c|c|c|c|c|c|c|}
\hline 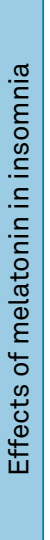 & 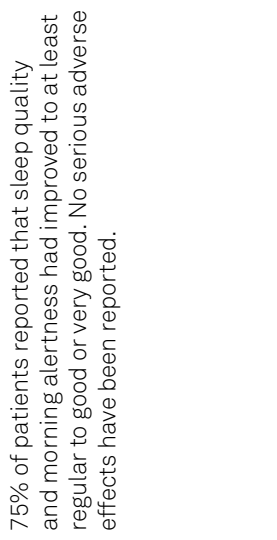 & 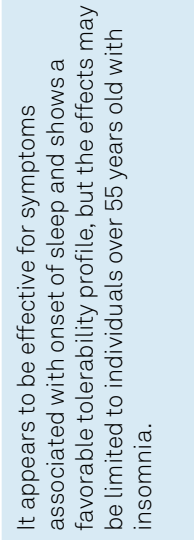 & 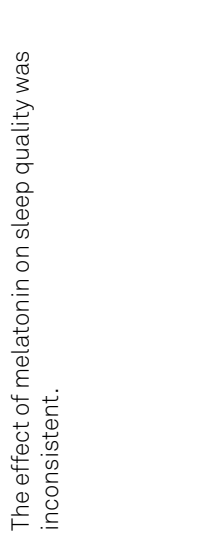 & 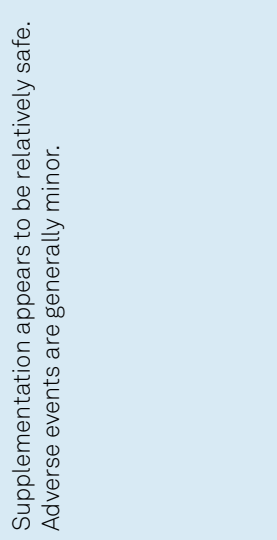 & 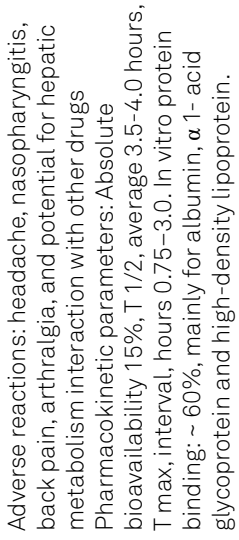 & 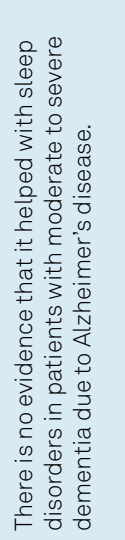 \\
\hline 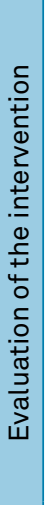 & 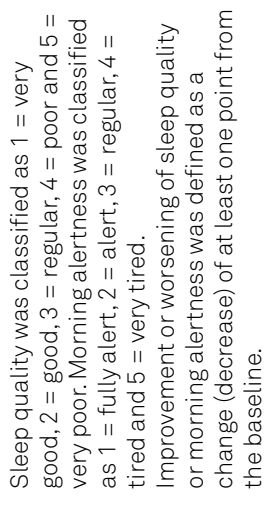 & 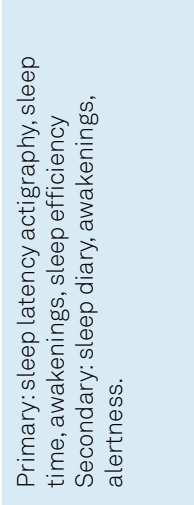 & 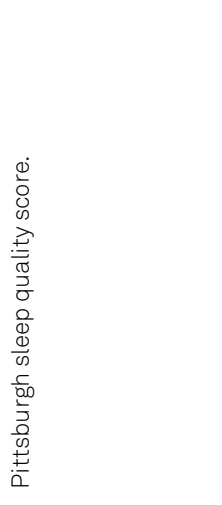 & 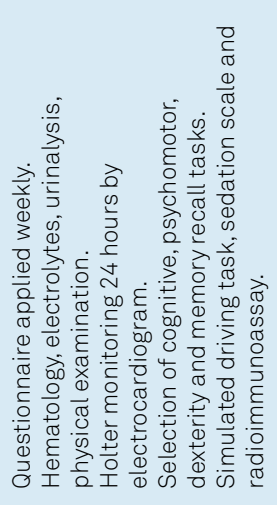 & 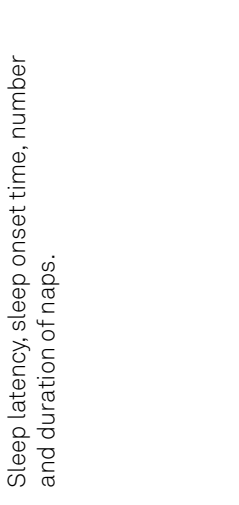 & 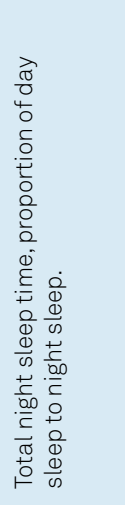 \\
\hline $\begin{array}{l}\text { वे. } \\
\text { 0 } \\
0 \\
0 \\
0 \\
0\end{array}$ & 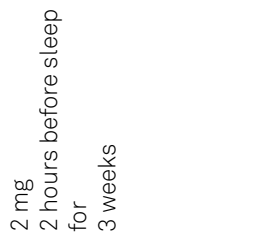 & 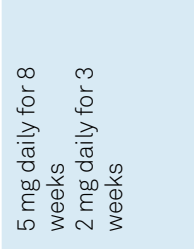 & 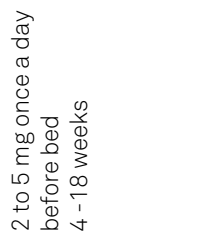 & 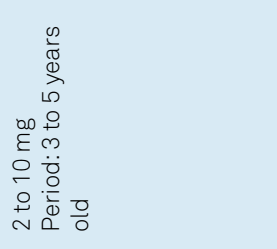 & 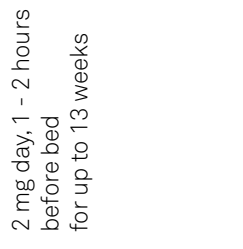 & 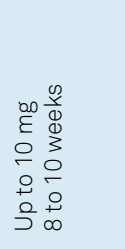 \\
\hline 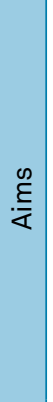 & 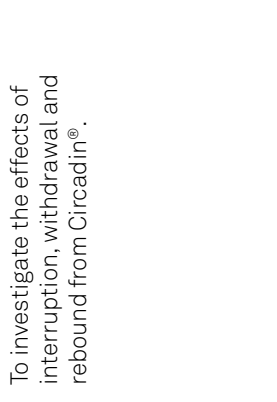 & 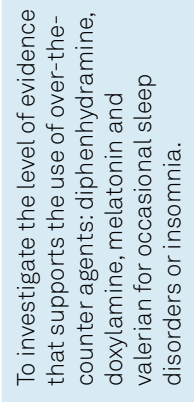 & 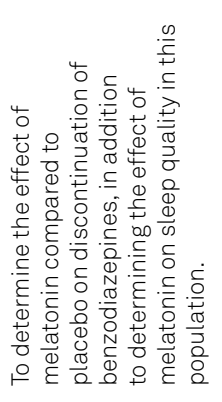 & 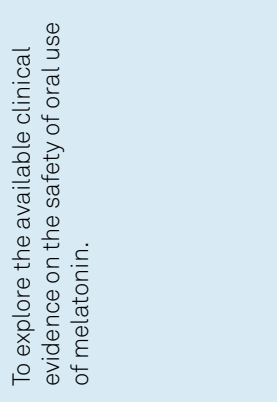 & 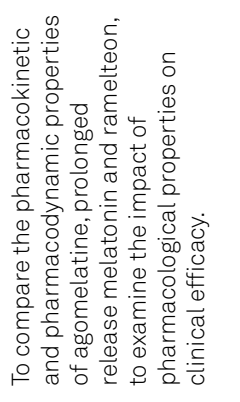 & 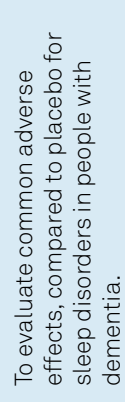 \\
\hline 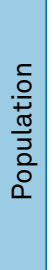 & 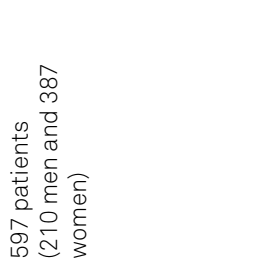 & 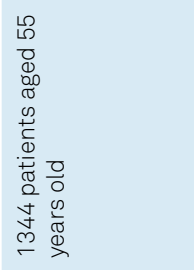 & 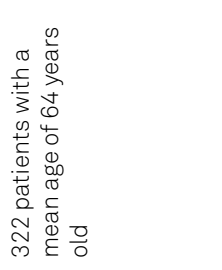 & 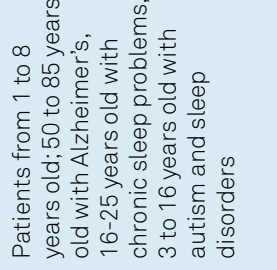 & 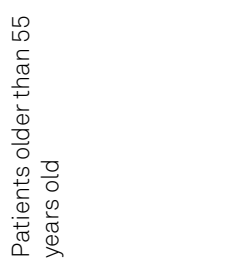 & 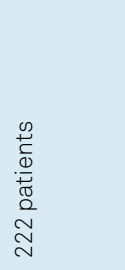 \\
\hline 竞 & 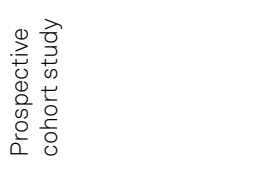 & 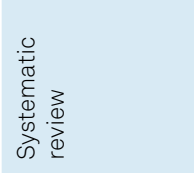 & 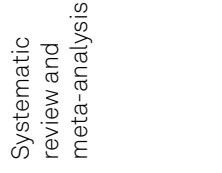 & 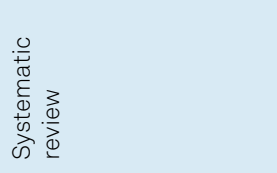 & $\begin{array}{l}\frac{3}{0} \\
\frac{1}{\mathbb{N}} \\
\simeq\end{array}$ & 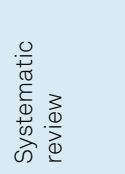 \\
\hline 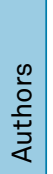 & 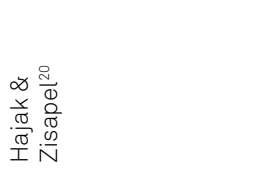 & 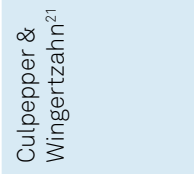 & 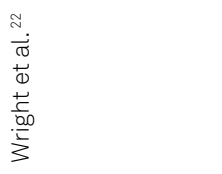 & 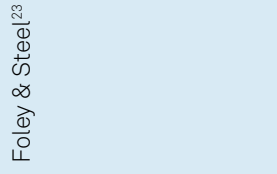 & 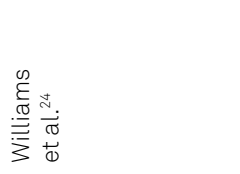 & 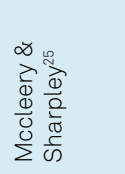 \\
\hline
\end{tabular}




\begin{tabular}{|c|c|c|c|c|c|c|}
\hline 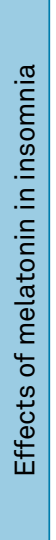 & 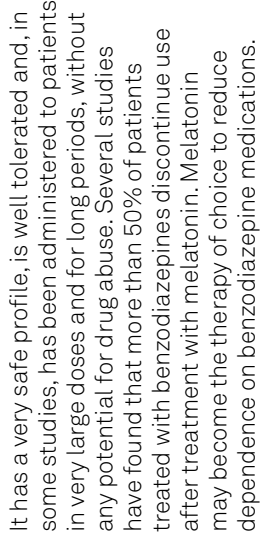 & 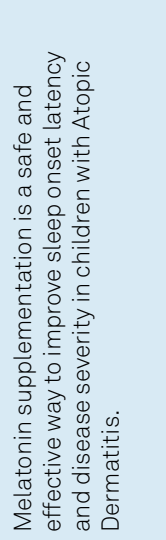 & 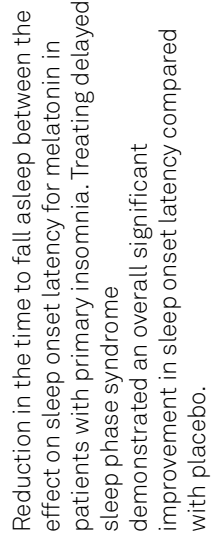 & 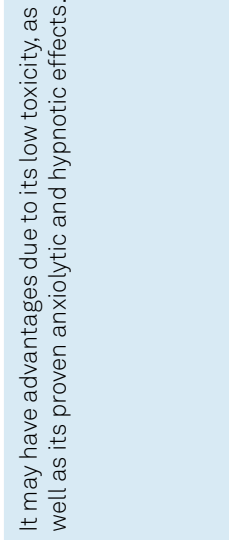 & 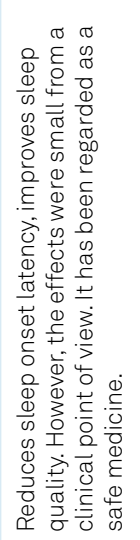 & 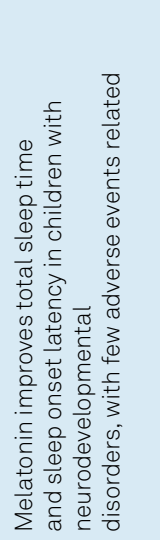 \\
\hline 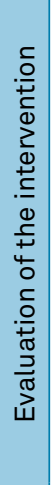 & 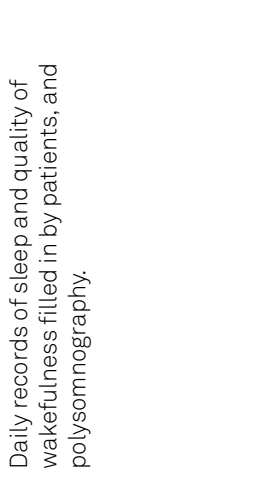 & 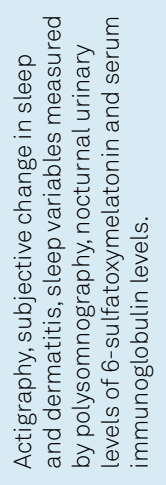 & 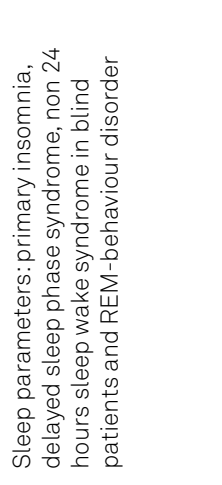 & 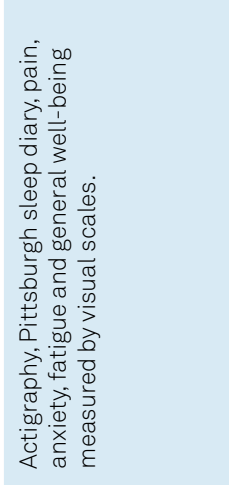 & 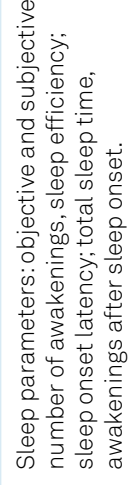 & 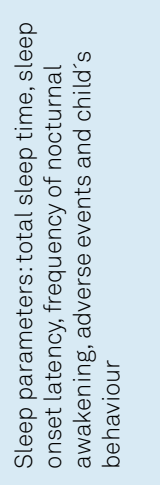 \\
\hline $\begin{array}{l}\text { के } \\
0 \\
0 \\
0 \\
0 \\
0\end{array}$ & 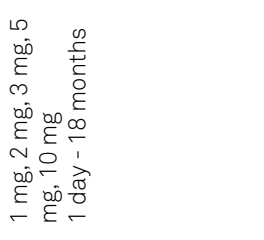 & 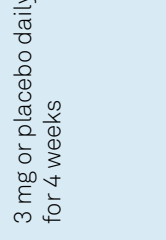 & 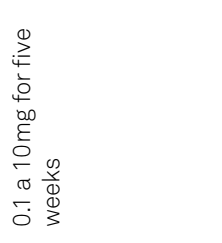 & 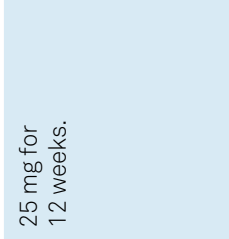 & 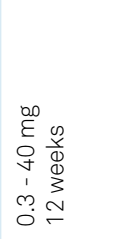 & 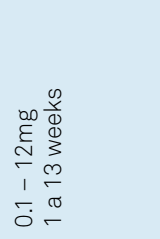 \\
\hline 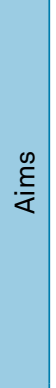 & 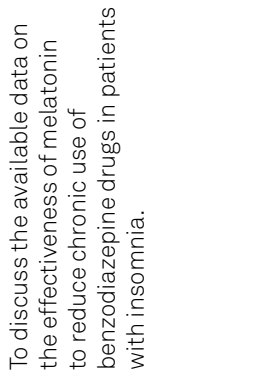 & 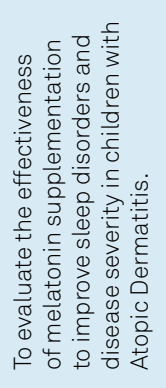 & 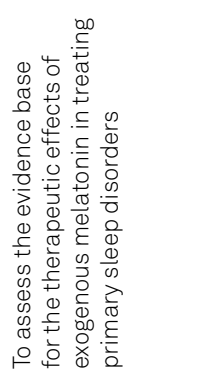 & 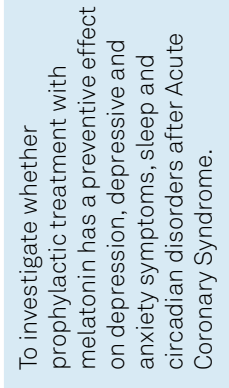 & 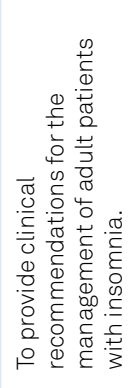 & 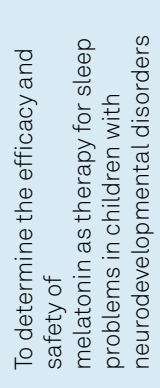 \\
\hline $\begin{array}{l}\stackrel{2}{0} \\
\frac{\pi}{+} \\
\frac{\pi}{3} \\
0 \\
0 \\
0\end{array}$ & 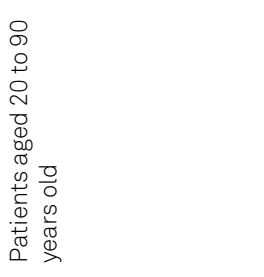 & 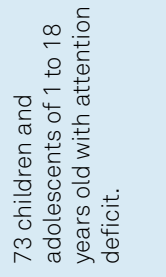 & 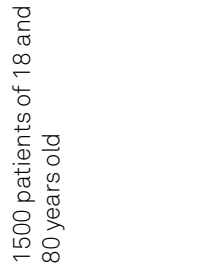 & 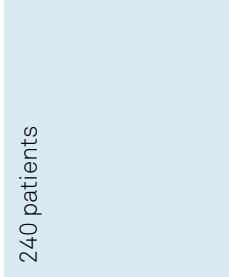 & 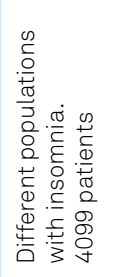 & 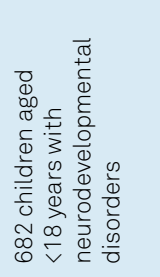 \\
\hline 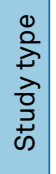 & 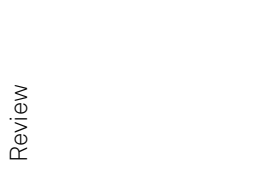 & 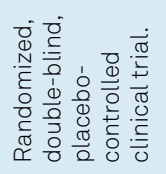 & 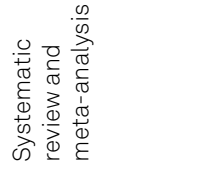 & 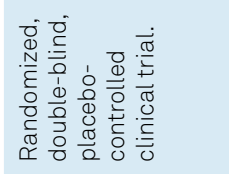 & 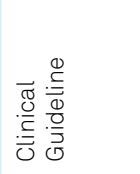 & 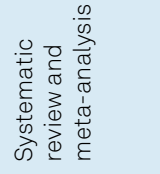 \\
\hline 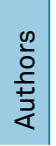 & 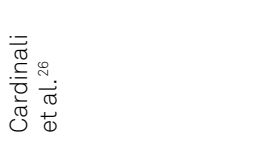 & 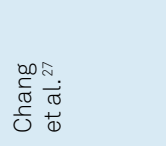 & 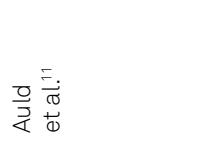 & 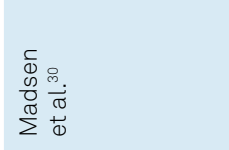 & 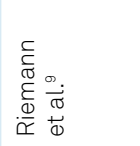 & 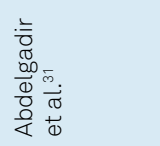 \\
\hline
\end{tabular}




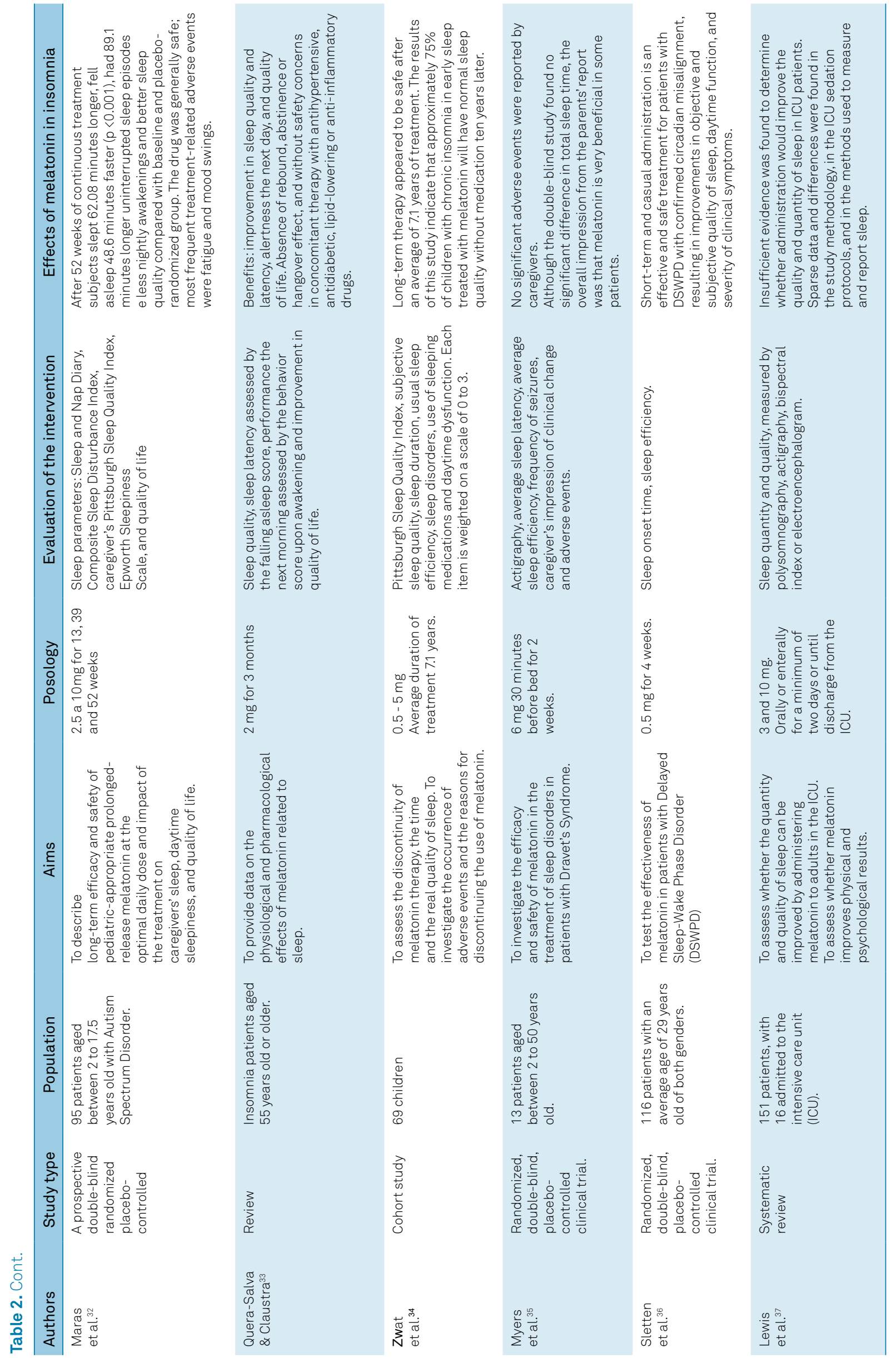




\begin{tabular}{|c|c|c|c|c|c|c|c|}
\hline 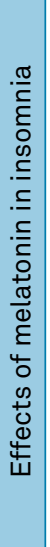 & 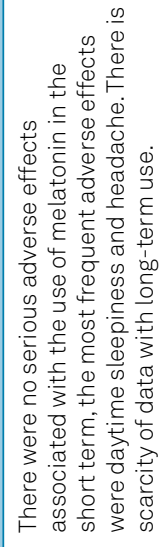 & 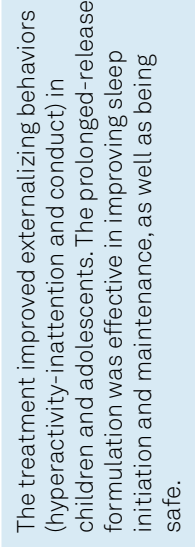 & 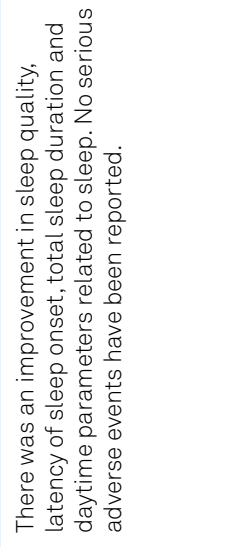 & 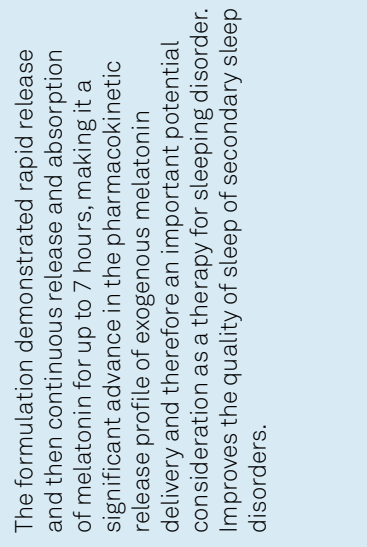 & 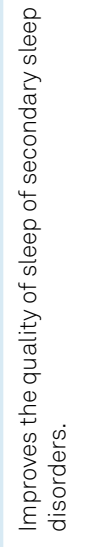 & 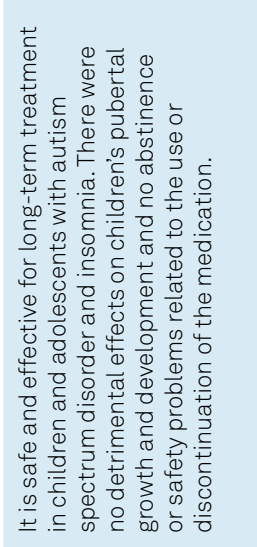 & 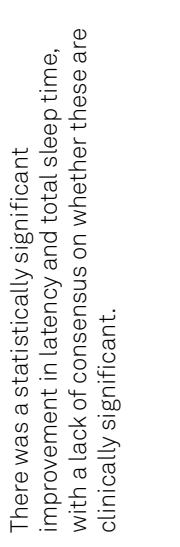 \\
\hline 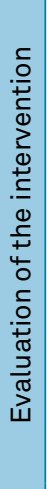 & 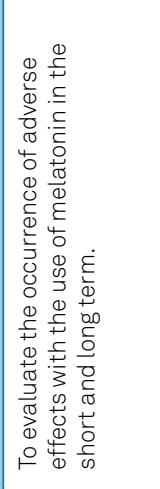 & 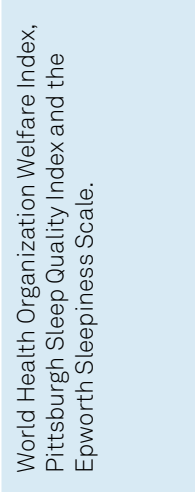 & 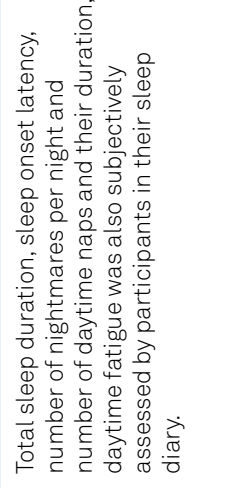 & 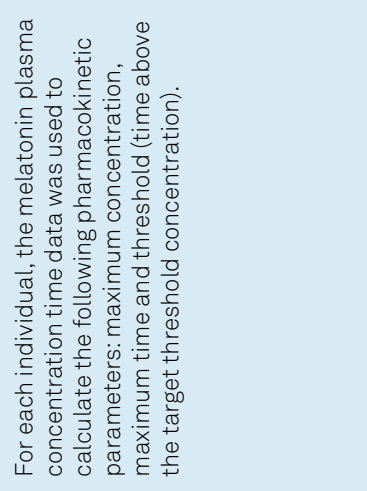 & 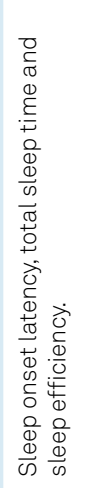 & 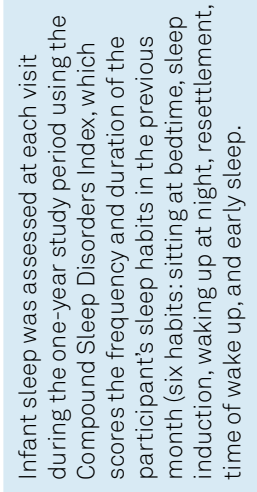 & 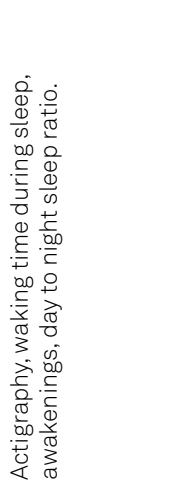 \\
\hline $\begin{array}{l}\text { वे. } \\
0 \\
0 \\
0 \\
0 \\
0\end{array}$ & 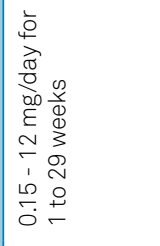 & & 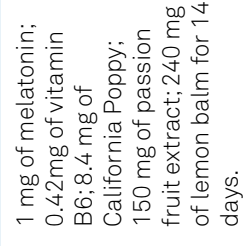 & 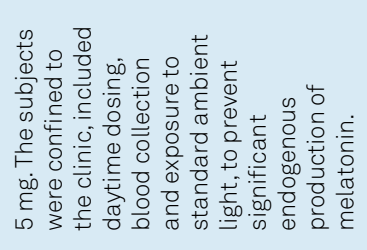 & 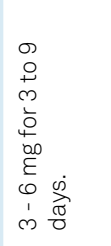 & 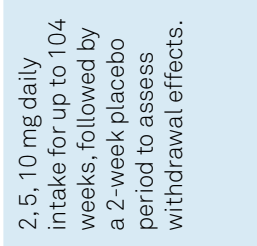 & 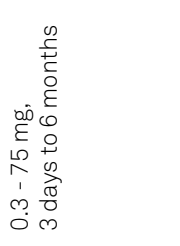 \\
\hline 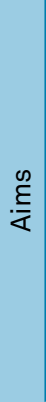 & 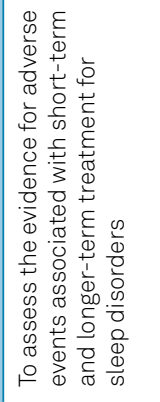 & 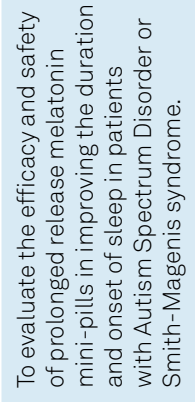 & 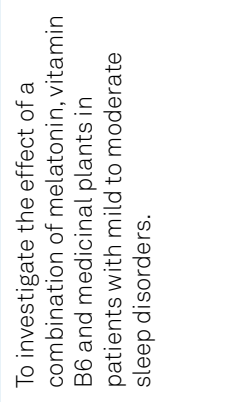 & 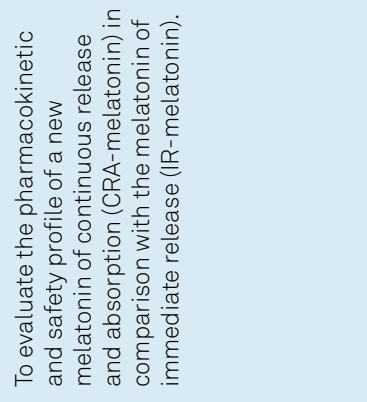 & 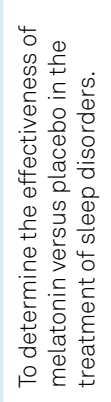 & 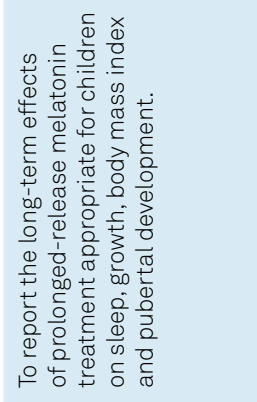 & 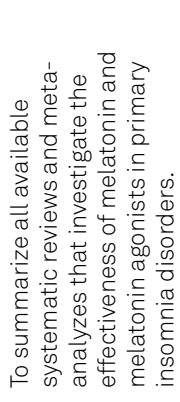 \\
\hline $\begin{array}{l} \\
\frac{0}{ \pm} \\
\frac{0}{3} \\
\frac{0}{0} \\
0\end{array}$ & 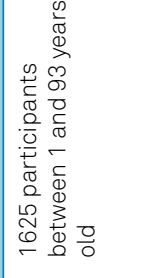 & 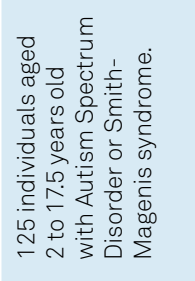 & 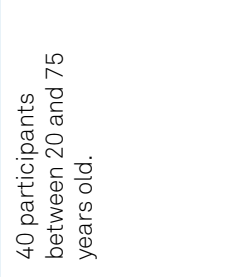 & 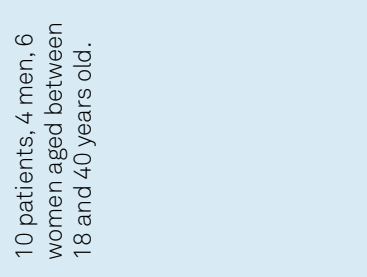 & 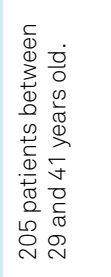 & 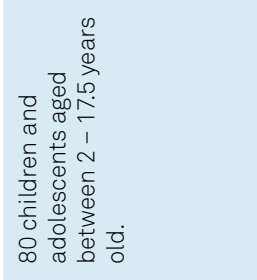 & 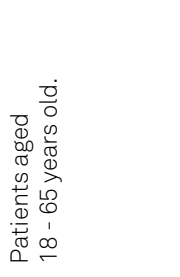 \\
\hline $\begin{array}{l}0 \\
0 \\
0 \\
0 \\
0 \\
0 \\
0\end{array}$ & 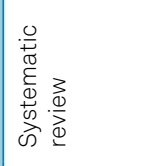 & 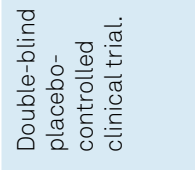 & 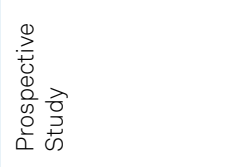 & 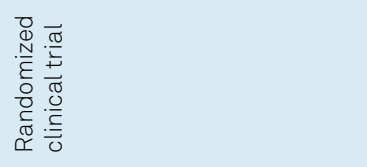 & 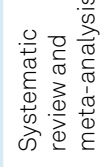 & 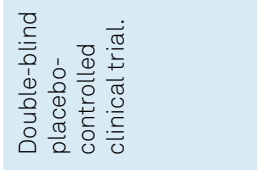 & 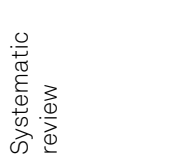 \\
\hline 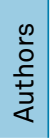 & 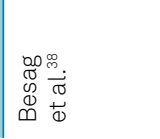 & 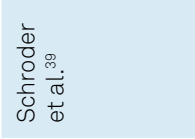 & 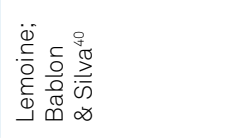 & 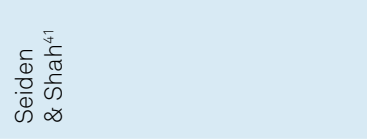 & ت. & 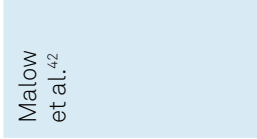 & 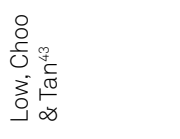 \\
\hline
\end{tabular}


Table 3. Melatonin dosages according to selected articles.

\begin{tabular}{lc}
\hline Population & Daily dose \\
\hline Children & $0.1 \mathrm{mg}-3 \mathrm{mg}$ \\
Teenagers & $3 \mathrm{mg}-12 \mathrm{mg}$ \\
Adults & $1 \mathrm{mg}-25 \mathrm{mg}$ \\
Elderly & $1 \mathrm{mg}-6 \mathrm{mg}$ \\
\hline
\end{tabular}

of melatonin used in these studies were equal to or higher than the doses indicated for healthy elderly people, however, the doses were lower compared to those used or studied in populations without dementia. Several different mechanisms are likely to cause sleep disorders in patients suffering from dementia, some of which may be related to circadian misalignment. Achieving full melatonin's chronobiotic effect in these circumstances can take several months. Therefore, it is possible that some patients respond after longer periods of treatment with melatonin ${ }^{25}$.

Overall, no significant adverse effects were reported in most studies; however, Besag et al. ${ }^{38}$ reported that daytime drowsiness and headache are among the most frequent related side effects. Similarly, Maras et al. ${ }^{32}$ stated that after 52 weeks of use of melatonin the most frequent treatmentrelated adverse events observed were fatigue and mood swings. Additionally, Myers et al. $^{35}$ in a randomized clinical study, reported that a patient had an increased serum level (within the toxic range) of valproate while using melatonin concomitantly. According to the authors, clinicians must ponder possible interactions of melatonin with antiepileptic drugs. Since melatonin is also metabolized by cytochrome P450 enzymes (CYP1A2, CYP1A1, and CYP2C19), the concomitant use of melatonin with antiepileptic and antidepressant drugs can potentially cause drug interaction. Consequently, the metabolism may be reduced leading to longer drug action time, which can cause severe sedation ${ }^{35}$.

A formulation containing melatonin, vitamin B6, California poppy extract, passion fruit extract, and lemon balm extract was tested on patients of both genders between 20 and 75 years old who had moderate insomnia. There was a statistically significant improvement in sleep quality during the two-week treatment period with no serious adverse events being reported, suggesting that this combination of assets is beneficial for mild to moderate insomnia ${ }^{40}$.

As for the doses, 0.1 to $0.5 \mathrm{mg}$ is recommended for sleeprelated rhythmic movement disorder, 1 to $5 \mathrm{mg}$ for sleep disorders, and 3 to $10 \mathrm{mg}$ for neurological diseases. These recommended doses should be taken daily, in a single dose at night, one hour before the usual bedtime. However, there is no established minimum or maximum effective dose for each use $^{29}$. Among the advantages of melatonin described in the included studies are its favorable safety profile, good toleration, and no addiction potential when administered for long periods ${ }^{26}$. The adverse reactions commonly found in the reviewed studies included headache, nasopharyngitis, back pain, arthralgia, nausea, dizziness, and restlessness ${ }^{20,24}$. Additionally, melatonin may have advantages attributed to its anxiolytic and hypnotic effects, and low toxicity levels, as reported by Madsen et al. ${ }^{30}$ while investigating the melatonin toxicity in patients with depressive, anxiety, and sleep disorder symptoms.

In Europe, the drug Circadin", which has a prolonged release formulation containing $2 \mathrm{mg}$ of melatonin, has been marketed since 2008 as an innovative treatment for primary insomnia in patients aged 55 years and older who have sleep disorders characterized by poor quality of sleep ${ }^{20}$. As a food supplement, it has not been evaluated or approved by the United States FDA to prevent or treat any diseases ${ }^{24}$.

In Brazil, there is no registration of drugs with melatonin as the active ingredient, therefore, its sale is prohibited in drugstores and national websites. Although melatonin is used in some countries as an ingredient in food supplements, this substance is not authorized for use in food supplements in Brazil. Additionally, according to the rules of Ordinance SVS / MS no 344/1998, melatonin is not an asset subject to special control, however, its commercialization is restricted to compounding pharmacists which must acquire the product from the company Active Pharmaceutica, have operation authorization granted by the ANVISA, and follow the current guidelines of Good Handling Practices. Additionally, prescription from a legally qualified professional is required, and the prescription must contain the composition, the pharmaceutical form, the dosage, and directions for use.

In this context, it is up to health professional bodies, especially doctors and pharmacists, to provide counseling to ensure the maintenance of therapy, symptom relief, functional changes, and assessment of potential adverse effects and drug interactions. These professionals must act in a multidisciplinary way, taking into account the benefit of reducing the use of benzodiazepine drugs, which can cause dependence, abuse, and contribute to higher costs of public resources resulting from the irrational use of medicines. Doctors and pharmacists can work together and offer the patient nonpharmacological and pharmacological treatments with the use of alternative, safe, and effective drugs such as melatonin.

In conclusion, it is evident from the identified studies that melatonin can be used in specific dosages according to age for sleep disorders, jet lag, insomnia in children with neurological disorders. Exogenous melatonin has emerged as an alternative therapy that can be used in sleep disorders. According to the evidence found, melatonin has not demonstrated toxicity or severe adverse effects, nor dependence even at high doses, demonstrating that its use is safe for treating young and elderly patients. However, despite the findings discussed, further investigations are needed in order to assess the dosages required for each age group, as well as dosages' safety profile.

Currently, no melatonin drug has been approved for use by regulatory bodies or legislation in Brazil, and the available 
information only determines the pharmaceutical form, excipient substance, and general guidelines for melatonin handling. Guidelines addressing the accurate use of melatonin to support clinicians and pharmacists in the treatment decision-making for sleep disorders is required. In addition, as melatonin is a relatively new drug, pharmacovigilance is essential, as it is up to health professionals to report any adverse events to the authorities.

\section{REFERÊNCIAS}

1. Sateia MJ. International classification of sleep disorders-third edition: highlights and modifications. Chest. 2014 Nov 1;146(5):138794. https://doi.org/10.1378/chest.14-0970

2. Fernandes RMF. O sono normal. Medicina (Ribeirão Preto). 2006 Jun 30;39(2):157-68. https://doi.org/10.11606/issn.2176-7262. v39i2p157-168

3. Buysse DJ. Insomnia.JAMA. 2013 Feb 20;309(7):706-16. https://doi. org/10.1001/jama.2013.193

4. Cao X-L, Wang S-B, Zhong B-L, Zhang L, Ungvari GS, Ng CH, et al. The prevalence of insomnia in the general population in China: a meta-analysis. PLoS One. 2017 Feb 24;12(2):e0170772. https://doi. org/10.1371/journal.pone.0170772

5. Torrens I, Argüelles-Vázquez R, Lorente-Montalvo P, Molero-Alfonso C, Esteva M. Prevalencia de insomnio y características de la población insomne de una zona básica de salud de Mallorca (España). Aten Primaria. 2019 Dec;51(10):617-25. https://doi.org/10.1016/j. aprim.2018.02.014

6. Castro LS, Poyares D, Leger D, Bittencourt L, Tufik S. Objective prevalence of insomnia in the São Paulo, Brazil epidemiologic sleep study. Ann Neurol. 2013 Oct;74(4):537-46. https://doi.org/10.1002/ ana. 23945

7. Nunes ML, Bruni O. Insomnia in childhood and adolescence: clinical aspects, diagnosis, and therapeutic approach. J Pediatr (Rio J). 2015 Nov-Dec;91(6 Suppl 1):S26-35. https://doi.org/10.1016/j. jped.2015.08.006

8. Ribeiro NF. Tratamento da insônia em atenção primária à saúde. Rev Bras Med Fam Comunidade. 2016 Jan-Dec;11(38):1-14. https://doi. org/10.5712/rbmfc11(38)1271

9. Riemann D, Baglioni C, Bassetti C, Bjorvatn B, Groselj LD, Ellis JG, et al. European guideline for the diagnosis and treatment of insomnia.J Sleep Res. 2017 Dec;26(6):675-700. https://doi.org/10.1111/jsr.12594

10. Vieira RB, Dantas A de A, Cayana EG. Suplementação da melatonina como alternativa terapêutica para insônia. II Congresso Brasileiro de Ciências da Saúde; 2017 Jun 14; Campina Grande, PB: Conbracis.

11. Auld F, Maschauer EL, Morrison I, Skene DJ, Riha RL. Evidence for the efficacy of melatonin in the treatment of primary adult sleep disorders. Sleep Med Rev. 2017 Aug;34:10-22. https://doi. org/10.1016/j.smrv.2016.06.005

12. Zisapel N. New perspectives on the role of melatonin in human sleep, circadian rhythms and their regulation. Br J Pharmacol. 2018 Aug;175(16):3190-9. https://doi.org/10.1111/bph.14116

13. Li T, Jiang S, Han M, Yang Z, Lv J, Deng C, et al. Exogenous melatonin as a treatment for secondary sleep disorders: a systematic review and meta-analysis. Front Neuroendocrinol. 2019 Jan;52:22-8. https://doi.org/10.1016/j.yfrne.2018.06.004

14. Grigg-Damberger MM, lanakieva D. Poor quality control of overthe-counter melatonin: what they say is often not what you get.J Clin Sleep Med. 2017 Feb 15;13(2):163-5. https://doi.org/10.5664/ jcsm. 6434

15. Erland LAE, Saxena PK. Melatonin natural health products and supplements: presence of serotonin and significant variability of melatonin content. J Clin Sleep Med. 2017 Feb 15;13(2):275-81. https://doi.org/10.5664/jcsm.6462

16. Anvisa [Internet]. Anvisa esclarece. Brasilia: Anvisa; 2020 [cited 2020 Jul 23]. Available from: https://www.gov.br/anvisa/pt-br/assuntos/ noticias-anvisa/2021/proposta-de-consulta-publica-inclui-a- melatonina-como-constituinte-autorizado/analise-da-seguranca-eeficacia-da-melatonina_versao-para-publicacao.pdf

17. Tribunal de Justiça de Minas Gerais. Apelação 10000190573444002 MG - Active Pharmaceutica Ltda ME. [cited 2020 Jul 21]. Available from: https://www.jusbrasil.com.br/processos/nome/53857300/ active-pharmaceutica-ltda-me

18. Bacelar A, Pinto Jr LR. Insônia: do diagnóstico ao tratamento. São Caetano do Sul (SP): Difusão Editora; 2019. 172p.

19. Mendes KDS, Silveira RC de CP, Galvão CM. Revisão integrativa: método de pesquisa para a incorporação de evidências na saúde e na enfermagem. Texto Contexto Enferm. 2008 Dec;17(4):758-64. https:// doi.org/10.1590/S0104-07072008000400018

20. Hajak G, Lemme K, Zisapel N. Lasting treatment effects in a postmarketing surveillance study of prolonged-release melatonin. Int Clin Psychopharmacol. 2015 Jan;30(1):36-42. https://doi. org/10.1097/YIC.0000000000000046

21. Culpepper L, Wingertzahn MA. Over-the-counter agents for the treatment of occasional disturbed sleep or transient insomnia: a systematic review of efficacy and safety. Prim Care Companion CNS Disord. 2015 Dec 31;17(6):10. https://doi.org/10.4088/PCC.15r01798

22. Wright A, Diebold J, Otal J, Stoneman C, Wong J, Wallace C, et al. The effect of melatonin on benzodiazepine discontinuation and sleep quality in adults attempting to discontinue benzodiazepines: a systematic review and meta-analysis. Drugs Aging. 2015 Dec;32(12):1009-18. https://doi.org/10.1007/s40266-015-0322-5

23. Foley HM, Steel AE. Adverse events associated with oral administration of melatonin: a critical systematic review of clinical evidence. Complement Ther Med. 2019 Feb;42:65-81. https://doi. org/10.1016/j.ctim.2018.11.003

24. Williams WPT, McLin DE, Dressman MA, Neubauer DN. Comparative review of approved melatonin agonists for the treatment of circadian rhythm sleep-wake disorders. Pharmacotherapy. 2016 Sep;36(9):1028-41. https://doi.org/10.1002/phar.1822

25. McCleery J, Cohen DA, Sharpley AL. Pharmacotherapies for sleep disturbances in dementia. Cochrane Database Syst Rev. 2016 Nov 16;11(11):CD009178. https://doi.org/10.1002/14651858.CD009178. pub3

26. Cardinali DP, Golombek DA, Rosenstein RE, Brusco LI, Vigo DE Assessing the efficacy of melatonin to curtail benzodiazepine/Z drug abuse. Pharmacol Res. 2016 Jul;109:12-23. https://doi.org/10.1016/j. phrs.2015.08.016

27. Chang Y-S, Lin M-H, Lee J-H, Lee P-L, Dai Y-S, Chu K-H, et al. Melatonin supplementation for children with atopic dermatitis and sleep disturbance: a randomized clinical trial. JAMA Pediatr. 2016 Jan;170(1):35-42. https://doi.org/10.1001/jamapediatrics.2015.3092

28. SBEM [Internet]. Posicionamento da SBEM sobre comercialização da melatonina. São Paulo: Sociedade Brasileira de Endocrinologia e Metabologia; [cited 2020 Jul 23]. Available from: https://www. endocrino.org.br/posicionamento-da-sbem-sobre-comercializacaoda-melatonina/

29. Associação Médica Brasileira. Sobre o uso e comercialização da Melatonina no Brasil, a Sociedade Brasileira de Endocrinologia e Metabologia (SBEM) esclarece. Rio de Janeiro: Sociedade Brasileira de Endocrinologia e Metabologia; 2016. [cited 2020 Jul 23]. Available from: https://www.endocrino.org.br/media/uploads/PDFs/ melatonina_sbem_2016_(1).pdf 
30. Madsen MT, Isbrand A, Andersen UO, Andersen LJ, Taskiran M, Simonsen E, et al. The effect of MElatonin on Depressive symptoms, Anxiety, Clrcadian and Sleep disturbances in patients after acute coronary syndrome (MEDACIS): study protocol for a randomized controlled trial. Trials. 2017 Feb 23;18(1):81. https://doi.org/10.1186/ s13063-017-1806-x

31. Abdelgadir IS, Gordon MA, Akobeng AK. Melatonin for the management of sleep problems in children with neurodevelopmental disorders: a systematic review and meta-analysis. Arch Dis Child. 2018 Dec;103(12):1155-62. https://doi.org/10.1136/ archdischild-2017-314181

32. Maras A, Schroder CM, Malow BA, Findling RL, Breddy J, Nir T, et al. Long-term efficacy and safety of pediatric prolonged-release melatonin for insomnia in children with Autism Spectrum Disorder. J Child Adolesc Psychopharmacol. 2018 Dec 10;28(10):699-710. https://doi.org/10.1089/cap.2018.0020

33. Quera-Salva M-A, Claustrat B. Melatonin: physiological and pharmacological aspects related to sleep: the interest of a prolonged-release formulation (Circadin $®$ ) in insomnia. Encephale. 2018 Dec;44(6):548-57. https://doi.org/10.1016/j.encep.2018.06.005

34. Zwart TC, Smits MG, Egberts TCG, Rademaker CMA, van Geijlswijk IM. Long-term melatonin therapy for adolescents and young adults with chronic sleep onset insomnia and late melatonin onset: evaluation of sleep quality, chronotype, and lifestyle factors compared to agerelated randomly selected population cohorts. Healthcare (Basel). 2018 Mar 2;6(1):23. https://doi.org/10.3390/healthcare6010023

35. Myers KA, Davey MJ, Ching M, Ellis C, Grinton BE, Roten A, et al. Randomized controlled trial of melatonin for sleep disturbance in dravet syndrome: the DREAMS study. J Clin Sleep Med. 2018 Oct 15;14(10):1697-1704. https://doi.org/10.5664/jcsm.7376

36. Sletten TL, Magee M, Murray JM, Gordon CJ, Lovato N, Kennaway DJ, et al. Efficacy of melatonin with behavioural sleep-wake scheduling for delayed sleep-wake phase disorder: a double-blind, randomised clinical trial. PLoS Med. 2018 Jun 18;15(6):e1002587. https://doi. org/10.1371/journal.pmed.1002587

37. Lewis SR, Pritchard MW, SchofieldDRobinson OJ, Alderson P, Smith AF. Melatonin for the promotion of sleep in adults in the intensive care unit. Cochrane Database Syst Rev. 2018 May 10;5(5):CD012455. https://doi.org//10.1002/14651858.CD012455.pub2

38. Besag FMC, Vasey MJ, Lao KSJ, Wong ICK. Adverse events associated with melatonin for the treatment of primary or secondary sleep disorders: a systematic review. CNS Drugs. 2019 Dec;33(12):1167-86. https://doi.org/10.1007/s40263-019-00680-w

39. Schroder CM, Malow BA, Maras A, Melmed RD, Findling RL, Breddy J, et al. Pediatric prolonged-release melatonin for sleep in children with Autism Spectrum Disorder: impact on child behavior and Caregiver's quality of life. J Autism Dev Disord. 2019 Aug 15;49(8):3218-30. https://doi.org/10.1007/s10803-019-04046-5

40. Lemoine P, Bablon J-C, Da Silva C. A combination of melatonin, vitamin B6 and medicinal plants in the treatment of mild-tomoderate insomnia: a prospective pilot study. Complement Ther Med. 2019 Aug;45:104-8. https://doi.org/10.1016/j.ctim.2019.05.024

41. Seiden DJ, Shah SM. A randomized, crossover, pharmacokinetics evaluation of a novel continuous release and absorption melatonin formulation. Prim Care Companion CNS Disord. 2019 Aug 1;21(4):19m02450. https://doi.org/10.4088/PCC.19m02450

42. Malow BA, Findling RL, Schroder CM, Maras A, Breddy J, Nir T, et al. Sleep, growth, and puberty after 2 years of prolonged-release melatonin in children with Autism Spectrum Disorder. J Am Acad Child Adolesc Psychiatry. 2021 Feb;60(2):252-61. https://doi. org/10.1016/j.jaac.2019.12.007

43. Low TL, Choo FN, Tan SM. The efficacy of melatonin and melatonin agonists in insomnia - an umbrella review. J Psychiatr Res. 2020 Feb;121:10-23. https://doi.org/10.1016/j.jpsychires.2019.10.022 